\title{
Orthophosphoric acid solutions of sodium orthovanadate, sodium tungstate, and sodium molybdate as potential corrosion inhibitors of the $\mathrm{Al}_{2} \mathrm{Cu}$ intermetallic phase
}

\author{
Przemysław Kwolek $^{1}$ (D) Kamil Dychtoń $^{1} \cdot$ Maciej Pytel $^{1}$
}

Received: 18 March 2019 /Revised: 7 September 2019 / Accepted: 8 September 2019/Published online: 7 October 2019

(C) The Author(s) 2019

\begin{abstract}
Orthophosphoric acid solutions of sodium orthovanadate, sodium tungstate, and sodium molybdate are tested as potential corrosion inhibitors of the $\mathrm{Al}_{2} \mathrm{Cu}$ intermetallic phase. Corrosion inhibition is observed for $0.2 \mathrm{M}$ solutions of $\mathrm{Na}_{3} \mathrm{VO}_{4}$ and $\mathrm{Na}_{2} \mathrm{WO}_{4}$ by increasing the $\mathrm{pH}$ to $>2$. When the $\mathrm{pH}$ is $<2$, the aforementioned salts increase the corrosion rate of the intermetallic phase. A $0.2 \mathrm{M}$ solution of $\mathrm{Na}_{3} \mathrm{VO}_{4}$ causes the precipitation of vanadium phosphate on the surface of the $\mathrm{Al}_{2} \mathrm{Cu}$ phase at $\mathrm{pH}=1$.
\end{abstract}

Keywords Intermetallics S Selective corrosion - Sodium molybdate Sodium orthovanadate - Sodium tungstate · Heteropolyanions

\section{Introduction}

The intermetallic $\mathrm{Al}_{2} \mathrm{Cu}$ phase is an important microstructural component of $\mathrm{Al}-\mathrm{Cu}-\mathrm{Mg}-\mathrm{Mn}$ and $\mathrm{Al}-\mathrm{Zn}-\mathrm{Mg}-\mathrm{Cu}$ wrought alloys because it ensures good strength by forming fine precipitates in the alloy matrix [1]. However, since it is nobler than the matrix, it promotes local dissolution and reduces the corrosion resistance of alloys [2, 3]. It is also well known that the formation of $\mathrm{Al}_{2} \mathrm{Cu}$ plays an important role in many $\mathrm{Al}-$ $\mathrm{Cu}$-based cast alloys [4-9]. The distribution of the $\mathrm{Al}_{2} \mathrm{Cu}$ phase in the interdendritic spacing affects both the mechanical and corrosion behaviour of the alloys [4-7]. This effect is not proportional, meaning that the microstructural refinement level and the cathode-to-anode area ratio strongly affect the mechanical-to-corrosion response [4, 8, 9]. At the same time, the intermetallic $\mathrm{Al}_{2} \mathrm{Cu}$ phase is itself susceptible to selective corrosion, and when immersed in acidic, neutral, and alkaline solutions, its surface is transformed into a highly porous metallic copper $[2,10]$.

The corrosion and wear resistance of components containing aluminium alloys can be improved by an appropriate

Przemysław Kwolek

pkwolek@prz.edu.pl

1 Department of Materials Science, Rzeszow University of Technology, Rzeszów, Poland surface treatment, which often requires acid etching, such as in the stripping of anodic coatings. In this case, a corrosion inhibitor is required for the metallic substrate, such as commonly used chromium trioxide [11]. However, due to its toxicity, new environmentally friendly inhibitors that are usable in acidic solutions must be developed, which requires understanding their influence on the corrosion behaviour of both the alloy and its microstructural constituents.

In this work, three inorganic salts, namely sodium orthovanadate $\left(\mathrm{Na}_{3} \mathrm{VO}_{4}\right)$, sodium tungstate $\left(\mathrm{Na}_{2} \mathrm{WO}_{4}\right)$ and sodium molybdate $\left(\mathrm{Na}_{2} \mathrm{MoO}_{4}\right)$, were tested as potential corrosion inhibitors of the intermetallic $\mathrm{Al}_{2} \mathrm{Cu}$ phase. A $0.5 \mathrm{M}$ solution of orthophosphoric acid $\left(\mathrm{H}_{3} \mathrm{PO}_{4}\right)$ was used as the corrosive environment because it is used in practice to strip anodic coatings [12].

The chemistry of the transition metals vanadium, niobium, tantalum, molybdenum and tungsten, in their highest oxidation states in aqueous solutions is very complex. When adding increasing amounts of a mineral acid to aqueous solutions of orthometalates (aka monometalates), addition and condensation processes progress and isopolyoxoanions are formed. They are built by a transition metal, oxygen and hydrogen. For the various equilibria, the resulting isopolyoxoanions are categorised in terms of their stoichiometric coefficients as described by the general equation (Eq. (1)):

$$
p \mathrm{MO}_{4}{ }^{2-}+q \mathrm{H}^{+} \rightarrow\left[\mathrm{M}_{\mathrm{p}} \mathrm{O}_{4 \mathrm{p}-\mathrm{q} / 2}\right]^{(2 \mathrm{p}-\mathrm{q})-}+\frac{q}{2} \mathrm{H}_{2} \mathrm{O}
$$


where $M=\mathrm{V}, \mathrm{Nb}, \mathrm{Ta}, \mathrm{Mo}$ or $\mathrm{W}$. The degree of protonation $Z$ of a particular species is defined by the ratio $q / p$. Heteropolyoxoanions incorporate one or more elements, in addition to the transition metal, oxygen and hydrogen.

The corrosion inhibition of aluminium alloys using isopolyoxovanadates was extensively studied in $\mathrm{NaCl}$ solutions [13-17]. In the mildly acidic solutions at low vanadate concentrations, tetrahedrally coordinated species, such as $\left[\mathrm{H}_{2} \mathrm{VO}_{4}\right]^{-}$and $\left[\mathrm{V}_{4} \mathrm{O}_{12}\right]^{4-}$, inhibited the cathodic process [14]. Decavanadate ions, such as $\left[\mathrm{HV}_{10} \mathrm{O}_{28}\right]^{5-}$ and $\left[\mathrm{H}_{2} \mathrm{~V}_{10} \mathrm{O}_{28}\right]^{4-}$, which are stable in mildly and strongly acidic solutions, do not exhibit an inhibiting effect on the 2024 alloy [13, 14]. Tetrahedrally coordinated isopolyoxovanadates decrease the corrosion potential and corrosion current density of intermetallic $\mathrm{Al}_{2} \mathrm{Cu}$ in $0.5 \mathrm{M}$ $\mathrm{NaCl}$ solutions $(\mathrm{pH}=9.17)$ and increase the pitting potential with little influence on the current density in the passive region of the anodic polarisation curve [15].

Isopolyoxotungstates were tested as corrosion inhibitors of aluminium in neutral and acidic solutions [18, 19]. Again, several stable species in aqueous solutions are possible, but the most common are paratungstate- $\mathrm{A}\left[\mathrm{W}_{7} \mathrm{O}_{24}\right]^{6-}$ and metatungstate $\left[\alpha-\mathrm{H}_{2} \mathrm{~W}_{12} \mathrm{O}_{40}\right]^{6-}[20]$. In acidic solution, isopolyoxotungstates increase the anodic and cathodic overpotentials and thus decrease the corrosion rate of $\mathrm{Al}$, but the inhibition efficiency is low (ca. 50\%) [19]. In a $0.5 \mathrm{M}$ $\mathrm{NaCl}$ solution, these species increase the pitting potential of aluminium due to adsorption at flawed areas and developing pits [18].

Isopolyoxomolybdates have rarely been tested as potential corrosion inhibitors of aluminium in acidic solutions. The most important isopolyoxomolybdates that can be formed are dimolybdate $\left[\mathrm{Mo}_{2} \mathrm{O}_{7}\right]^{2-}$, trimolybdate $\left[\mathrm{Mo}_{3} \mathrm{O}_{10}\right]^{2-}$, tetramolybdate $\left[\mathrm{Mo}_{4} \mathrm{O}_{13}\right]^{2-}$, heptamolybdate (also called paramolybdate) $\left[\mathrm{Mo}_{7} \mathrm{O}_{24}\right]^{6-}$, octamolybdate $\left[\mathrm{Mo}_{8} \mathrm{O}_{26}\right]^{4-}$ and decamolybdate $\left[\mathrm{Mo}_{10} \mathrm{O}_{34}\right]^{8-}$; also, many large clusters, such as $\left[\mathrm{Mo}_{36} \mathrm{O}_{112}\left(\mathrm{H}_{2} \mathrm{O}\right)_{16}\right]^{8-},\left[\mathrm{Mo}_{154}(\mathrm{NO})_{14} \mathrm{O}_{420}(\mathrm{OH})_{28}\left(\mathrm{H}_{2} \mathrm{O}\right)_{70}\right]^{25-}$ and $\mathrm{Na}_{48}\left[\mathrm{H}_{x} \mathrm{Mo}_{368} \mathrm{O}_{1032}\left(\mathrm{H}_{2} \mathrm{O}\right)_{240}\left(\mathrm{SO}_{4}\right)_{48}\right] \cdot$ ca. $1000 \mathrm{H}_{2} \mathrm{O}(x \approx$ 16 ), can be formed [20-23]. Regarding their inhibiting properties, it was demonstrated that in $1 \mathrm{M} \mathrm{HCl}$, isopolyoxomolybdates increased the corrosion rate of aluminium [24], but in a chloridefree borate buffer (possibly containing a small amount of $\mathrm{H}_{3} \mathrm{PO}_{4}$ ), the corrosion rate of aluminium and its alloys decreased. It was concluded that isopolyoxomolybdates behaved as passivators when Mo atoms were incorporated into the surface film [25].

Heteropolyoxoanions can be formed by about 60 elements on the periodic table, but one of the most important is phosphorus. Vanadium forms heteropolyoxoanions less frequently than molybdenum and tungsten, and known species include $\left[\mathrm{PV}_{14} \mathrm{O}_{42}\right]^{9-}$ and $\left[\mathrm{H}_{6} \mathrm{PV}_{13} \mathrm{O}_{41}\right]^{7-}[20]$. The most notable example of a heteropolyoxotungstate is $\left[\mathrm{PW}_{12} \mathrm{O}_{40}\right]^{3-}$; however, in the presence of excess $\mathrm{H}_{3} \mathrm{PO}_{4}$, which occurs when sodium tungstate is used as the corrosion inhibitor in orthophosphoric acid, $\left[\mathrm{P}_{4} \mathrm{~W}_{8} \mathrm{O}_{40}\right]^{12-}$ can be formed [20]. Neither heteropolyoxovanadates nor heteropolyoxotungstates have been tested as corrosion inhibitors of aluminium; thus, heteropolyoxomolybdates are somewhat exceptional from this point of view. The most well-known heteropolyoxomolybdate is $\left[\mathrm{PMo}_{12} \mathrm{O}_{40}\right]^{3-}$, which is a more powerful oxidant than $\left[\mathrm{PW}_{12} \mathrm{O}_{40}\right]^{3-}$ and can be easily reduced to phosphomolybdenum blue species $\left[\mathrm{PMo}_{12} \mathrm{O}_{40}\right]^{7-}$, which are widely used in analytical chemistry [26]. The corrosion inhibition of aluminium and 2024 aluminium alloy in the $\mathrm{H}_{3} \mathrm{PO}_{4}-\mathrm{Na}_{2} \mathrm{MoO}_{4}$ system has been demonstrated [24, 27-29]. Interestingly, iso- and heteropolyoxomolybdates also decrease the dissolution rate of anodic coatings in solutions of orthophosphoric acid [30].

\section{Experimental}

$\mathrm{Al}_{2} \mathrm{Cu}$ electrodes were obtained by an electrical arc melting process in water-cooled copper crucibles using a tungsten electrode under an Ar atmosphere $(p=60 \mathrm{kPa})$. Stoichiometric amounts of $\mathrm{Al}$ and $\mathrm{Cu}(99.999 \mathrm{wt} \%$ purity, Alfa Aesar) were weighed to obtain approximately $4.5 \mathrm{~g}$ of the alloy with a theoretical $\mathrm{Cu}$ content of $53.4 \mathrm{wt} \%$. The feedstock material was re-melted four times to obtain a homogeneous material. A small amount of a eutectic mixture of $\mathrm{Al}_{2} \mathrm{Cu}$ and $\mathrm{Al}(\mathrm{Cu})$ solid solution crystals was obtained together with the hypereutectic crystals of the $\mathrm{Al}_{2} \mathrm{Cu}$ phase. The former was dissolved during subsequent heat treatment in air $(T=823 \mathrm{~K}, t$ $=30 \mathrm{~h}$ ). X-ray diffraction confirmed that $\mathrm{Al}_{2} \mathrm{Cu}$ was obtained (International Centre for Diffraction Data (ICDD) card 04001-0923). Subsequently, the specimens were cut using an electrical discharge machine and mounted in an epoxy resin. The surface area of the electrodes was approximately $0.79 \mathrm{~cm}^{2}$. Prior to the corrosion tests, they were abraded by $\mathrm{SiC}$ papers (320 and 500 grit), washed with water and isopropyl alcohol, and then dried with flowing air.

Corrosion tests were performed in a conventional threeelectrode electrochemical cell open to air with a water jacket and equipped with platinum counter electrodes $\left(20 \mathrm{~cm}^{2}\right)$. The reference electrode $(\mathrm{Ag} / \mathrm{AgCl}$ in $3 \mathrm{M} \mathrm{KCl})$ was placed in a Luggin probe filled with $1 \mathrm{M} \mathrm{KNO}_{3}$ solution. The volume of tested solutions was $100 \mathrm{~cm}^{3}$ at a temperature $T$ of $303 \mathrm{~K}$. The electrochemical cell was placed in a Faraday cage and connected to a Bio-Logic SP-300 potentiostat.

$\mathrm{Na}_{3} \mathrm{VO}_{4}, \mathrm{Na}_{2} \mathrm{WO}_{4}$ and $\mathrm{Na}_{2} \mathrm{MoO}_{4}$ were dissolved in $0.5 \mathrm{M}$ orthophosphoric acid. Concentrations equal to 10,50,100 and $200 \mathrm{mM}$ were obtained. The open-circuit potential (OCP) of $\mathrm{Al}_{2} \mathrm{Cu}$ was recorded for $10 \mathrm{~h}$, and within this period, the impedance spectra were measured. The first one was obtained at $t=20 \mathrm{~min}$, and subsequent ones were obtained every $2 \mathrm{~h}$. The frequency domain of the spectra was between $200 \mathrm{kHz}$ and $10 \mathrm{mHz}$ with $5 \mathrm{mV}$ of a root mean square (RMS) of sinusoidal perturbation of potential. The impedance spectra were validated using a Kramers-Kronig transformation (KK Test software) 
$[31,32]$. Only spectra obtained under stationary conditions are presented in this work. They were approximated using the appropriate equivalent circuit in Zview software (Scribner Associates). Values of the fitted parameters were normalised to the geometric surface area of the specimen, i.e. $0.79 \mathrm{~cm}^{2}$. The quality of the fit was estimated using two parameters: $\chi^{2}$ (chi squared) and $S$. The former, in the Zview software, is defined as the square of the standard deviation between the measured and calculated data. The latter is the weighted sum of squares of differences between measured and calculated data, where the weighting factors are the moduli of calculated impedances.

The influence of $\mathrm{pH}$ on the corrosion kinetics of the $\mathrm{Al}_{2} \mathrm{Cu}$ phase was established based on additional corrosion experiments. The following solutions were used: $0.5 \mathrm{M} \mathrm{H}_{3} \mathrm{PO}_{4} /$ $0.2 \mathrm{M} \mathrm{Na}_{3} \mathrm{VO}_{4}$ and $0.5 \mathrm{M} \mathrm{H}_{3} \mathrm{PO}_{4} / 0.2 \mathrm{M} \mathrm{Na}_{2} \mathrm{WO}_{4}$ at $\mathrm{pH} 1.0$ as well as $0.5 \mathrm{M} \mathrm{Na}_{3} \mathrm{PO}_{4}$ at $\mathrm{pH} 2.2$ and 3.9. The $\mathrm{pH}$ was adjusted using concentrated $\mathrm{H}_{2} \mathrm{SO}_{4}$.

The aluminium and copper concentrations in solutions after corrosion tests were measured using inductively coupled plasma-optical emission spectroscopy ICP-OES (Ultima 2 Horiba Jobin Yvon). Due to a significant matrix effect, the standard addition method was applied. The morphology and chemical composition of the surface of corroded $\mathrm{Al}_{2} \mathrm{Cu}$ specimens were determined using scanning electron microscopy (SEM) on a HITACHI S-3400N equipped with energydispersive X-ray spectrometer (EDX) (Thermo Noran System 7).

\section{Results and discussion}

\section{Corrosion rate of intermetallic $\mathrm{Al}_{2} \mathrm{Cu}$}

Sodium orthovanadate, sodium molybdate and sodium tungstate form isopolyoxoanions and heteropolyoxoanions when they are dissolved in orthophosphoric acid solution. They were tested as corrosion inhibitors of intermetallic $\mathrm{Al}_{2} \mathrm{Cu}$. The concentration of aluminium $c_{\mathrm{Al}}$ and copper $c_{\mathrm{Cu}}$ in the solution was determined as a function of the initial concentration of the monometalates after $10 \mathrm{~h}$ of immersion (Fig. 1). The intermetallic phase in the acidic solution was susceptible to selective corrosion. Aluminium atoms were preferentially dissolved, and the electrode surface was enriched with copper and became porous. In $0.5 \mathrm{M} \mathrm{H}_{3} \mathrm{PO}_{4}$, for instance, $c_{\mathrm{Al}}$ was approximately 300 -fold higher than $c_{\mathrm{Cu}}$. Thus, it can be concluded that the $c_{\mathrm{Al}} / c_{\mathrm{Cu}}$ depends on the added inorganic salt and its initial concentration.

Sodium orthovanadate, when used at a low concentration $(10 \mathrm{mM})$, significantly increased the corrosion rate of the intermetallic phase (Fig. 1a). However, when its concentration was $\geq 100 \mathrm{mM}$, it inhibited the corrosion process. Additionally, under such conditions, the $\mathrm{Al}_{2} \mathrm{Cu}$ phase did not selectively corrode. Sodium tungstate influenced the corrosion kinetics of the intermetallic phase in a similar manner. However, it was a less efficient inhibitor than $\mathrm{Na}_{3} \mathrm{VO}_{4}$ (Fig. 1b). Interestingly, when its concentration was $<200 \mathrm{mM}$, a white powder precipitated, along with the corrosion of the intermetallic phase. However, the powder contained neither aluminium nor copper and was mainly composed of tungsten (ca. 17 at\%) and oxygen with a small admixture of phosphorus and sodium. Thus, it was likely one of the heteropolyoxotungstate forms. Sodium molybdate, in turn, increased the corrosion rate of the $\mathrm{Al}_{2} \mathrm{Cu}$ phase in the whole studied concentration range $(10-200 \mathrm{mM})$ and was excluded from further analysis.

On the one hand, the monometalates $\mathrm{Na}_{3} \mathrm{VO}_{4}$ and $\mathrm{Na}_{2} \mathrm{WO}_{4}$, when dissolved in an acid, increase its $\mathrm{pH}$. On the other hand, the $\mathrm{Al}_{2} \mathrm{Cu}$ phase is passive over a wide $\mathrm{pH}$ range between 2 and 10 [33]. Therefore, understanding the corrosion behaviour of $\mathrm{Al}_{2} \mathrm{Cu}$ required determining the $\mathrm{pH}$ of the solutions prior to the corrosion experiments (Fig. 2). The corrosion inhibition may be related to an increase in the $\mathrm{pH}$ of the solutions. This possibility was further explored using electrochemical impedance spectroscopy (EIS).

\section{Electrochemical analysis}

The corrosion kinetics of the $\mathrm{Al}_{2} \mathrm{Cu}$ phase was studied in $0.5 \mathrm{M}$ $\mathrm{H}_{3} \mathrm{PO}_{4}, 0.5 \mathrm{M} \mathrm{H}_{3} \mathrm{PO}_{4} / 0.01 \mathrm{M} \mathrm{Na}_{3} \mathrm{VO}_{4}$ and $0.5 \mathrm{M} \mathrm{H}_{3} \mathrm{PO}_{4} / 0.2 \mathrm{M}$ $\mathrm{Na}_{3} \mathrm{VO}_{4}$ at $\mathrm{pH}=1.0,1.3$ and 3.9, respectively, as well as $0.5 \mathrm{M}$ $\mathrm{H}_{3} \mathrm{PO}_{4} / 0.05 \mathrm{M} \mathrm{Na}_{2} \mathrm{WO}_{4}$ and $0.5 \mathrm{M} \mathrm{H}_{3} \mathrm{PO}_{4} / 0.2 \mathrm{M} \mathrm{Na}_{2} \mathrm{WO}_{4}$ at $\mathrm{pH}=1.2$ and 2.2, respectively. Additional corrosion tests were performed in $0.5 \mathrm{M} \mathrm{H}_{3} \mathrm{PO}_{4} / 0.2 \mathrm{M} \mathrm{Na}_{3} \mathrm{VO}_{4}$ and $0.5 \mathrm{M} \mathrm{H}_{3} \mathrm{PO}_{4} /$ $0.2 \mathrm{M} \mathrm{Na}_{2} \mathrm{WO}_{4}$ acidified to $\mathrm{pH}=1.0$ as well as $0.5 \mathrm{M} \mathrm{Na}_{3} \mathrm{PO}_{4}$ acidified to $\mathrm{pH}=3.9$ and 2.2.

Immediately after immersion in acidic solution, the $\mathrm{Al}_{2} \mathrm{Cu}$ corroded via hydrogen and oxygen depolarisation. The appearance of the electrode surface changed from shiny to dull and copper-like, which was caused by the selective dissolution of aluminium atoms. The porous structure, composed of $\mathrm{Cu}$, was formed on the surface of the electrode (Fig. 3a). The open-circuit potential of the electrode increased with time (Fig. 4a). When it was $>-267 \mathrm{mV}$ vs. a $\mathrm{Ag} / \mathrm{AgCl}$ reference electrode (equilibrium potential of standard hydrogen electrode at $\mathrm{pH}=1$ ), the corrosion mechanism changed to oxygen depolarisation. The same mechanism was responsible for corrosion of $\mathrm{Al}_{2} \mathrm{Cu}$ in $0.5 \mathrm{M} \mathrm{H}_{3} \mathrm{PO}_{4} /$ $0.01 \mathrm{M} \mathrm{Na}_{3} \mathrm{VO}_{4}$ and $0.5 \mathrm{M} \mathrm{H}_{3} \mathrm{PO}_{4} / 0.05 \mathrm{M} \mathrm{Na}_{2} \mathrm{WO}_{4}$. When the initial concentration of sodium orthovanadate was equal to $0.2 \mathrm{M}$, the open-circuit potential achieved the highest value. The OCP was relatively low, in turn, in $0.5 \mathrm{M} \mathrm{H}_{3} \mathrm{PO}_{4} / 0.2 \mathrm{M}$ $\mathrm{Na}_{2} \mathrm{WO}_{4}$ at $\mathrm{pH}=1.0$ (Fig. 4b).

Electrochemical impedance spectroscopy was used to study the influence of the chemical composition of the solutions on the corrosion mechanism of $\mathrm{Al}_{2} \mathrm{Cu}$. First, the modulus of the imaginary part of impedance was analysed as a 
a)

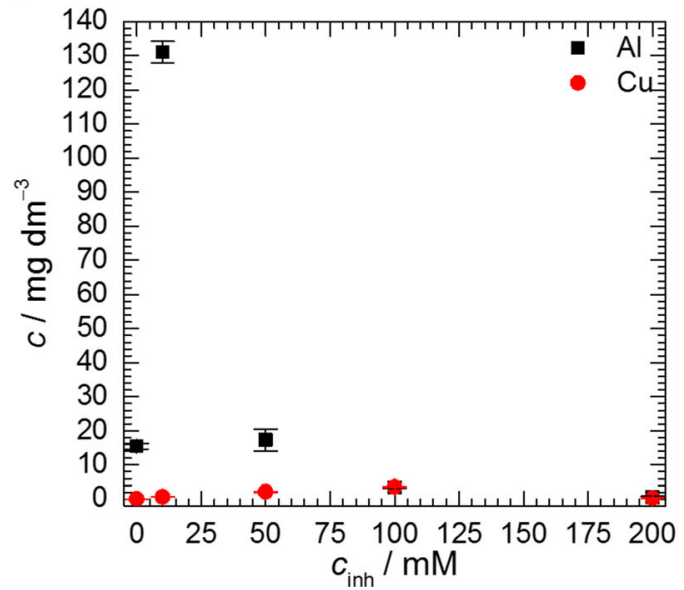

b)

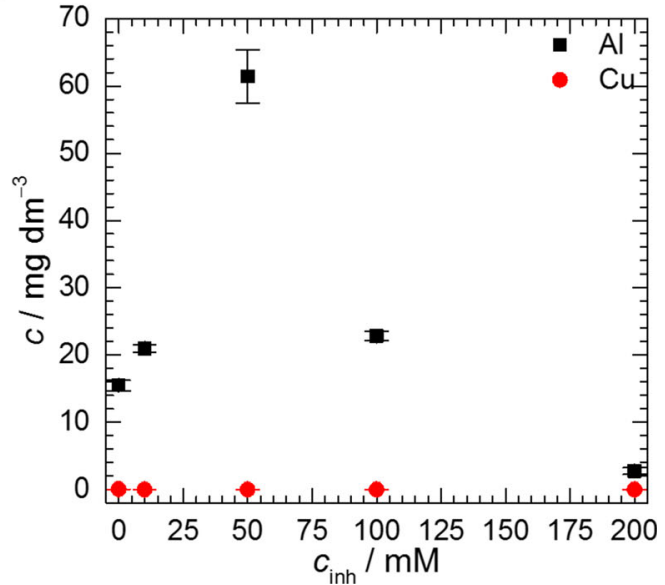

Fig. 1 Concentration of $\mathrm{Cu}$ and $\mathrm{Al}$ in $0.5 \mathrm{M} \mathrm{H}_{3} \mathrm{PO}_{4}$ solutions after $t=10 \mathrm{~h}$ immersion of intermetallic $\mathrm{Al}_{2} \mathrm{Cu}, T=303 \mathrm{~K}$, as a function of the initial concentration of $\mathbf{a ~} \mathrm{Na}_{3} \mathrm{VO}_{4}$ and $\mathbf{b} \mathrm{Na}_{2} \mathrm{WO}_{4}$

function of frequency (Fig. 5). It can be observed that in the high-frequency range $>10 \mathrm{kHz},\left|Z^{\prime \prime}\right|$ decreased as the frequency decreased. It is usually regarded as an artefact related to the impedance of the reference electrode, stray capacitance from the cable connected to the voltage amplifier and its input capacitance [34]. Therefore, this frequency range was excluded from the approximation. However, Orazem et al. observed and discussed similar behaviour for selectively corroded cast iron. In their results, the high-frequency part of the spectrum, in the form of the incomplete capacitive loop in the Nyquist plot, was related to the microporous film present on the surface of the cast iron and the cathodic charge-transfer process [35].

A subsequent linear increase in $\log \left|Z^{\prime \prime}\right|$ can be observed for the selectively corroded $\mathrm{Al}_{2} \mathrm{Cu}$ phase, usually between $70 \mathrm{kHz}$ and $100 \mathrm{~Hz}$ (Fig. 5) [35]. The impedance spectra of such porous electrodes can be approximated using the de Levie model; however, the important parameters characterizing the electrochemical process, such as the charge-transfer resistance $R_{\text {ct }}$ and the double-layer capacitance $C_{\mathrm{dl}}$, cannot be estimated easily [36]. Lasia et al. proposed a so-called two CPE model,

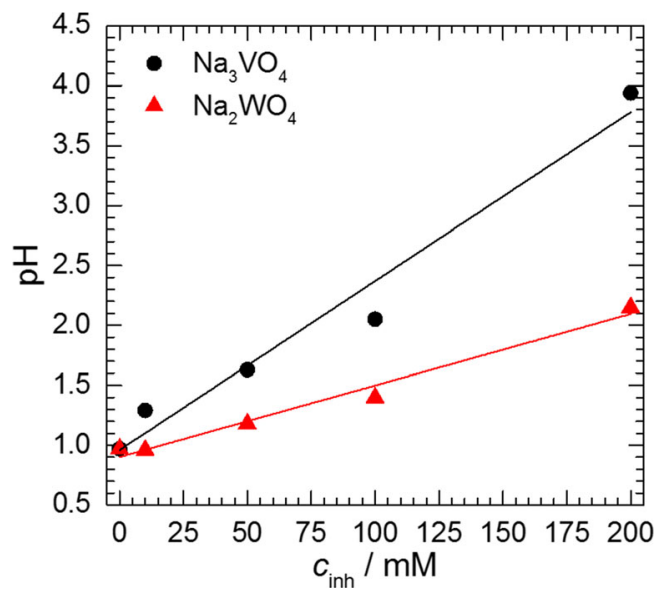

Fig. 2 The $\mathrm{pH}$ of the solutions of $\mathrm{Na}_{3} \mathrm{VO}_{4}$ and $\mathrm{Na}_{2} \mathrm{WO}_{4}$ in $0.5 \mathrm{M} \mathrm{H}_{3} \mathrm{PO}_{4}$ in which a high-frequency capacitive loop is related to a porous film on the surface of the electrode and a low-frequency loop is related to its corrosion $[37,38]$. In our case, however, using the "two CPE" model gave high approximation errors of the electrical equivalent circuit (EEC) elements. Therefore, the high-frequency range of the impedance spectra was not approximated. Only in the case of a solution containing $200 \mathrm{mM}$ $\mathrm{Na}_{3} \mathrm{VO}_{4}$ at $\mathrm{pH}=1.0$ was a well-established capacitive loop in this range of frequencies visible.

Another straight line in Fig. 5 can be observed over a wide range of frequencies down to ca. $1 \mathrm{~Hz}$. This corresponds to the double-layer capacitance $C_{\mathrm{dl}}$ connected in parallel to the charge-transfer resistance $R_{\mathrm{ct}}$. However, due to the frequency dispersion, the negative value of the slope is $<1$; thus, a constant phase element $\left(C P E_{\mathrm{d} 1}\right)$ was used instead of a capacitor in the EEC (Figs. 6 and 8). The impedance of the CPE is given by Eq. (2) [39, 40]:

$Z_{\mathrm{CPE}}=\frac{1}{T(j \omega)^{\alpha}}$

where $T$ is the parameter related to the electrode capacitance, $\omega$ is the angular frequency and $\alpha$ indicates the deviation from purely capacitive behaviour. When $\alpha=1, T$ equals the capacitance. It seems reasonable that time constants for the faradaic process were distributed along, rather than normal to, the surface of the electrode. Thus, the following equation can be applied to obtain the double-layer capacitance $C_{\mathrm{dl}}$ (Eq. (3)) [40-42]:

$C_{\mathrm{dl}}=T_{\mathrm{dl}} \frac{1}{\alpha}\left(\frac{R_{\mathrm{s}} R_{\mathrm{ct}}}{R_{\mathrm{s}}+R_{\mathrm{ct}}}\right)^{\frac{1-\alpha}{\alpha}}$

where $R_{\mathrm{s}}$ is the solution resistance, $R_{\mathrm{ct}}$ is the charge-transfer resistance, $T_{\mathrm{dl}}$ is the parameter of the constant phase element representing the electrical double layer and $\alpha$ is the exponent 
Fig. 3 Scanning electron micrograph of the $\mathrm{Al}_{2} \mathrm{Cu}$ surface after $10 \mathrm{~h}$ exposure in a $0.5 \mathrm{M}$ $\mathrm{H}_{3} \mathrm{PO}_{4}$ and b $0.5 \mathrm{M} \mathrm{H}_{3} \mathrm{PO}_{4} / 0.2 \mathrm{M}$ $\mathrm{Na}_{3} \mathrm{VO}_{4}$ at $\mathrm{pH}=1.0$ and $T=$ $303 \mathrm{~K}$
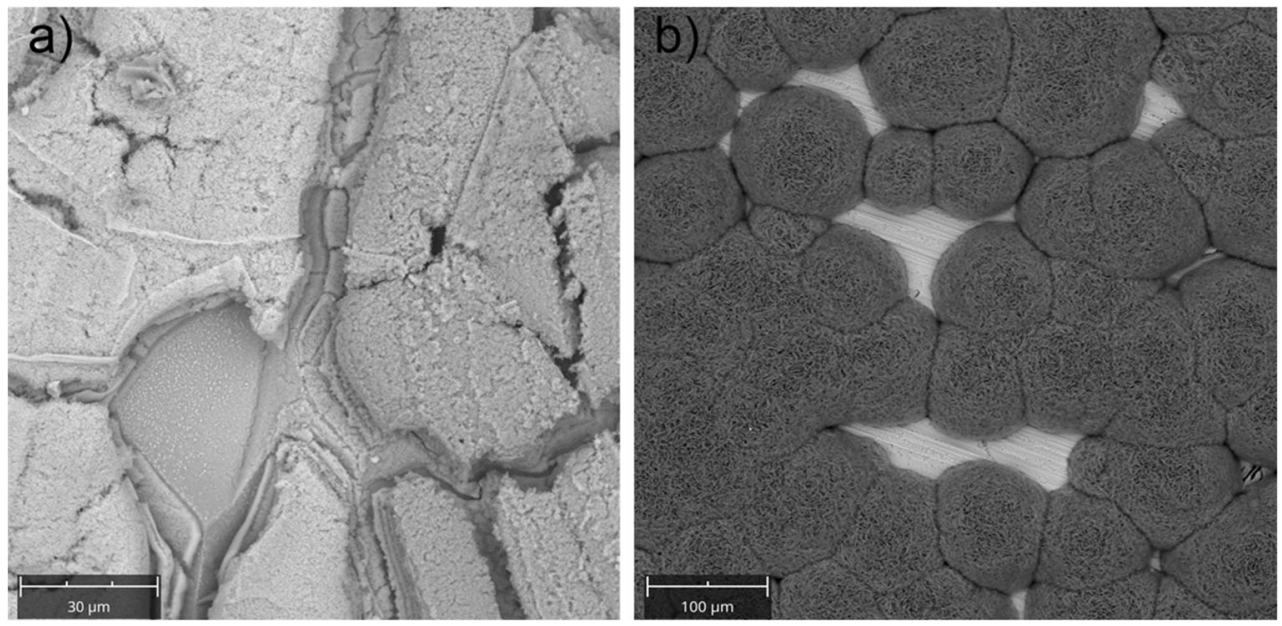

of the CPE. It should be noted here that when $\alpha<0.85$, calculation of $C_{\mathrm{d} 1}$ using Eq. (3) can lead to significant error [43].

An additional time constant was observed for frequencies < $1 \mathrm{~Hz}$. The inductive behaviour in the Nyquist plots (e.g. Fig. 6a) was approximated by the inductor $L_{1}$ in series with a resistor $R_{1}$. These are related to the adsorption of intermediate species due to the anodic dissolution of metal and/or corrosion inhibitor species [40]. The same model can be applied to a passive electrode. The resistance then takes into account the kinetics of changes to the fractional surface coverage or film resistivity with time, whereas inductance is related to the time constant of this process [44]. The low-frequency inductive behaviour of corroding metal is frequently observed (e.g., $[24,45]$ and $[46]$ in the case of aluminium in acidic solutions and intergranular corrosion of stainless steel, respectively).

In the case of $200 \mathrm{mM} \mathrm{Na}_{3} \mathrm{VO}_{4}$ at $\mathrm{pH}=3.9$, the inductorcontaining equivalent circuit was not applicable. A much better approximation was achieved using the alternative model for the passive electrode, where a constant phase element was applied instead of a capacitor (Fig. 6b) [40]. The physical meaning of $C P E_{1}$ and $R_{2}$ is not straightforward, but they are related to the charge-transfer resistance, the change in the electric current passing through the interface caused by a change in the fractional coverage of the surface, film resistivity, or thickness, as well as the time constants related to these processes [40]. An additional time constant, visible for $200 \mathrm{mM} \mathrm{Na}_{3} \mathrm{VO}_{4}$ at $\mathrm{pH}=1.0$ (Fig. 5) for $f<100 \mathrm{mHz}$, was not approximated.

The impedance spectra obtained for the $\mathrm{Al}_{2} \mathrm{Cu}$ phase in the solutions without corrosion inhibitors at $\mathrm{pH} \geq 2.2(0.5 \mathrm{M}$ $\mathrm{Na}_{3} \mathrm{PO}_{4}$ ) were well approximated with a simple, Randlestype equivalent circuit (Figs. 5 and 6c, d).

The impedance spectra obtained for the corrosion of $\mathrm{Al}_{2} \mathrm{Cu}$ in $0.5 \mathrm{M} \mathrm{H}_{3} \mathrm{PO}_{4} / 0.2 \mathrm{M} \mathrm{Na}_{2} \mathrm{WO}_{4}$ and $0.5 \mathrm{M} \mathrm{H}_{3} \mathrm{PO}_{4} / 0.2 \mathrm{M}$ $\mathrm{Na}_{3} \mathrm{VO}_{4}$ with their approximation using an electrical equivalent circuit are presented in Fig. 6a, b, respectively. Relatively high values of the impedance, especially for the sodium a)

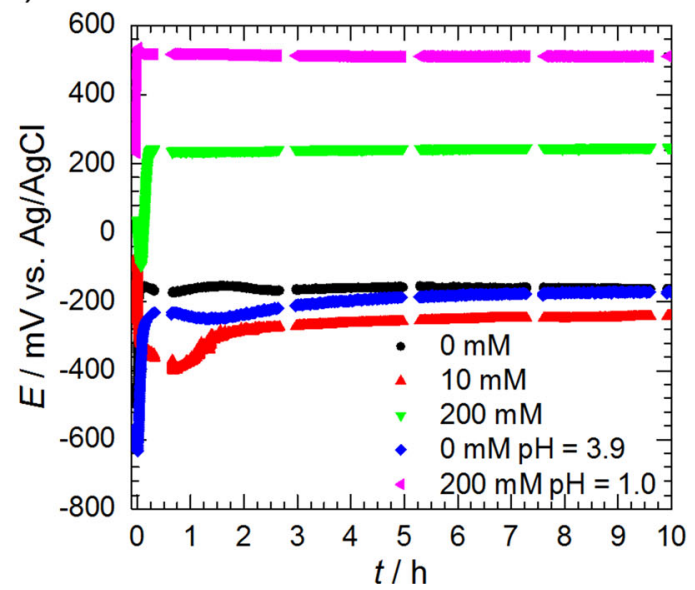

b)

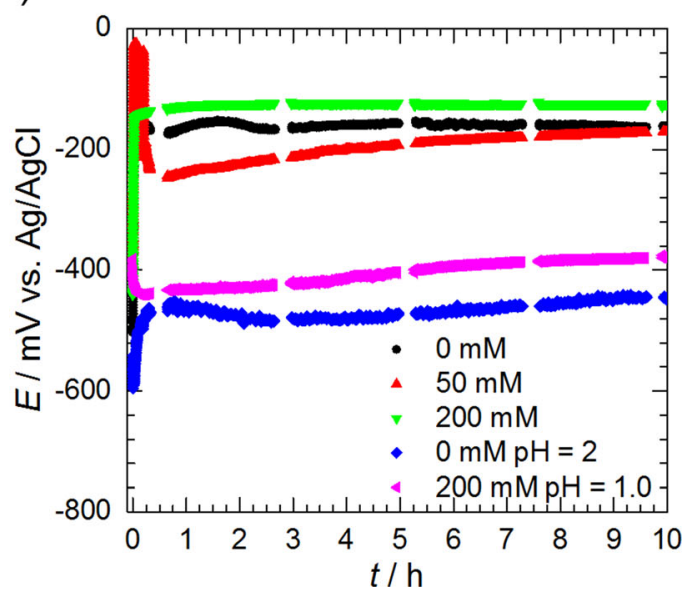

Fig. 4 Open-circuit potential of $\mathrm{Al}_{2} \mathrm{Cu}$ in $0.5 \mathrm{M} \mathrm{H}_{3} \mathrm{PO}_{4}$ at $T=303 \mathrm{~K}$ as a function of time, $\mathrm{pH}$ and initial concentration of a sodium orthovanadate and b sodium tungstate 


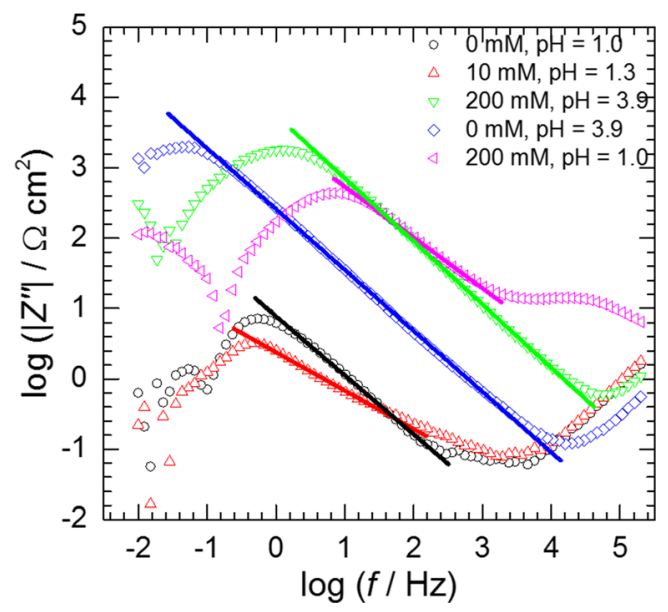

Fig. 5 Modulus of the imaginary part of impedance as a function of frequency for $\mathrm{Al}_{2} \mathrm{Cu}$ exemplary corrosion processes in the presence of $\mathrm{Na}_{3} \mathrm{VO}_{4}$; impedances were multiplied by the geometric surface area

orthovanadate, suggest efficient corrosion inhibition. However, similarly high impedances were obtained for the

a)

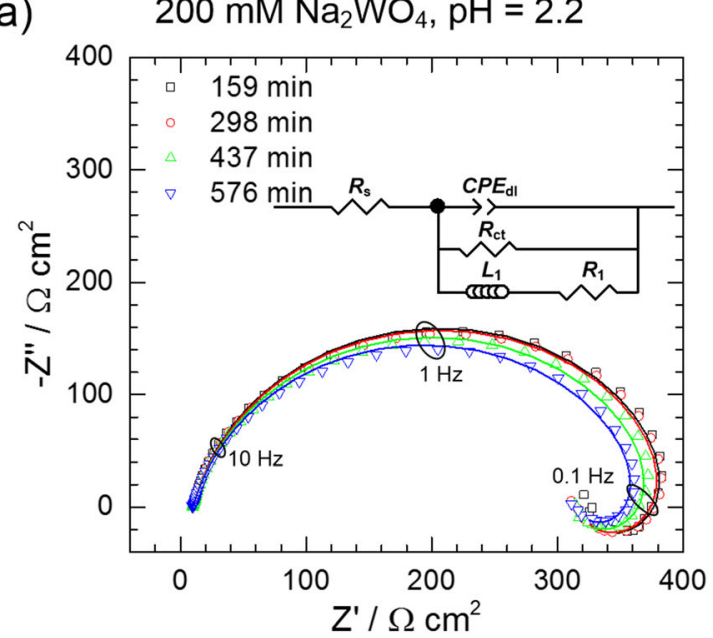

$\mathrm{Al}_{2} \mathrm{Cu}$ in $0.5 \mathrm{M} \mathrm{Na}_{3} \mathrm{PO}_{4}$ acidified to $\mathrm{pH}=2.2$ and 3.9 (Fig. $6 \mathrm{c}, \mathrm{d})$.

The double-layer capacitance calculated for the $\mathrm{Al}_{2} \mathrm{Cu}$ phase immersed in $0.5 \mathrm{M} \mathrm{Na}_{3} \mathrm{PO}_{4}$ at $\mathrm{pH}=2.2$ was very high when compared to the typical value for smooth metal surfaces $\left(20 \mu \mathrm{F} \mathrm{cm}^{-2}\right)$ [37] and increased with time from 2195 to $6389 \mu \mathrm{F} \mathrm{cm}^{-2}$. Lasia reported even higher values that reached $2.4 \mathrm{~F} \mathrm{~cm}^{-2}[37,38]$. This is related to the enormous increase of surface area of the electrode caused by the selective dissolution of Al (Fig. 3a). The double-layer capacitance increases with time as the surface area of the electrode increases. In this work, capacitances were divided by the geometric surface area, i.e. $0.79 \mathrm{~cm}^{2}$. The real value, however, changes with time and can be between several hundred and several thousand times higher when compared to the initial value. The exact value remains unknown. Therefore, the increase of $C_{\mathrm{dl}}$ with time is observed. In fact, it is only related to the aggressiveness of the corrosive environment.

For $200 \mathrm{mM}$ of $\mathrm{Na}_{2} \mathrm{WO}_{4}$ in turn, the double-layer capacitance was equal to ca. $190 \mu \mathrm{F} \mathrm{cm}{ }^{-2}$ and did not change with
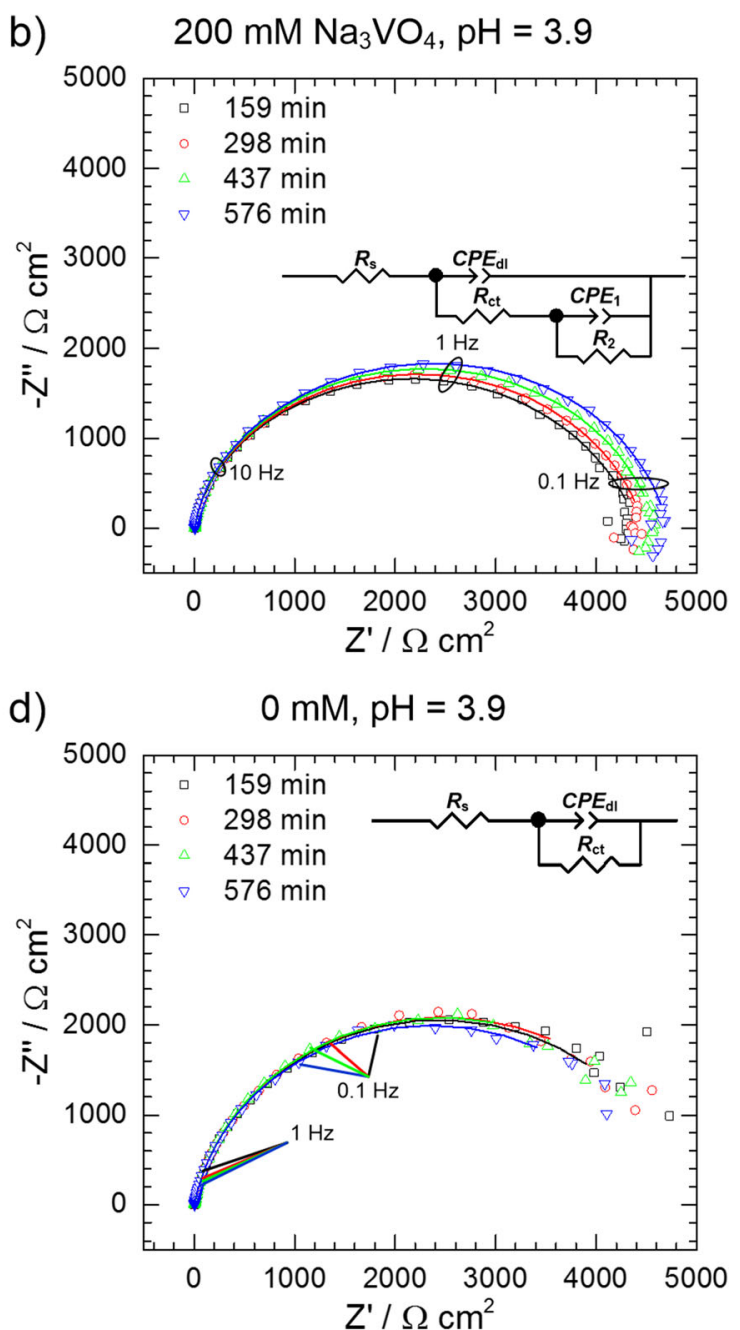

c)

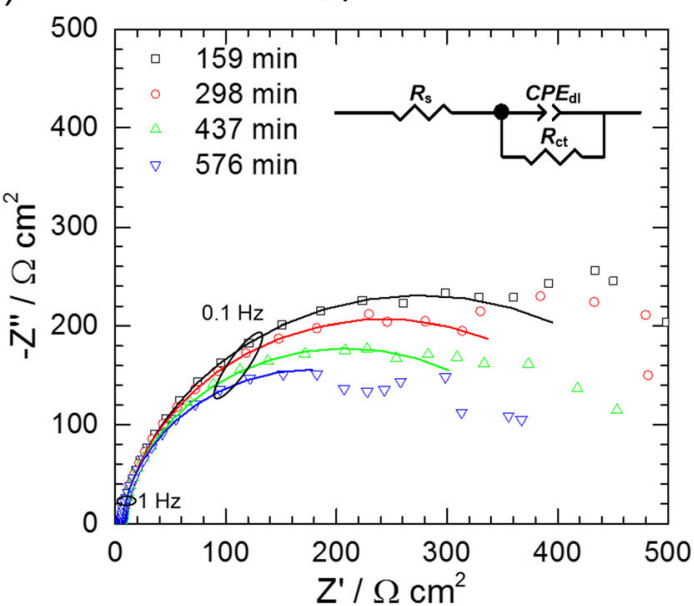

Fig. 6 Nyquist plots for the corrosion of $\mathrm{Al}_{2} \mathrm{Cu}$ as a function of time in $\mathbf{a}, \mathbf{b} 0.5 \mathrm{M} \mathrm{H}_{3} \mathrm{PO}_{4}$ and $\mathbf{c}, \mathbf{d} 0.5 \mathrm{M} \mathrm{Na}_{3} \mathrm{PO}_{4}$ at $T=303 \mathrm{~K}$; continuous lines represent an approximation of the obtained data, impedances were multiplied by the geometric surface area 
a)

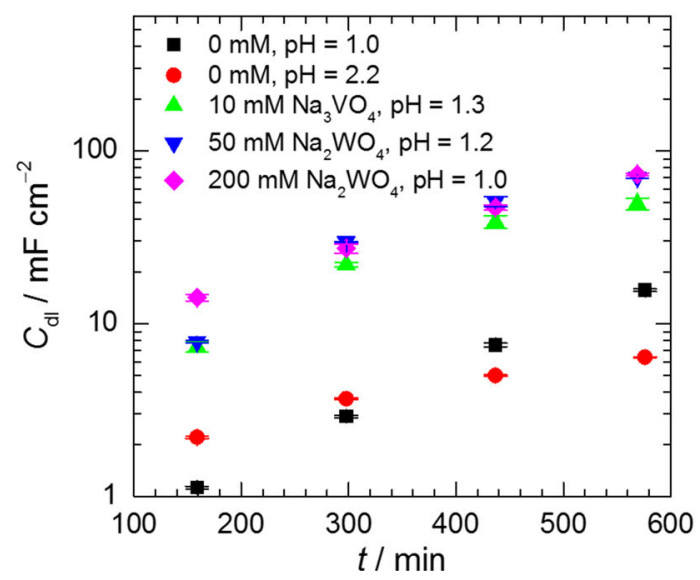

b)

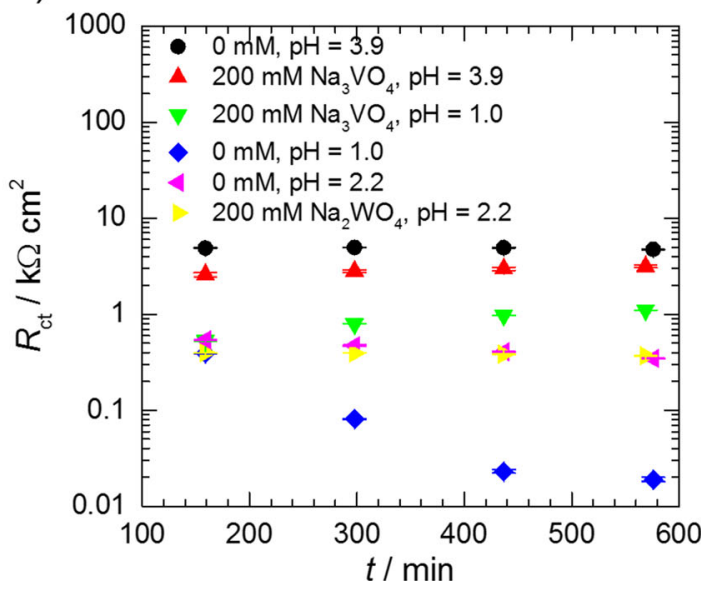

Fig. 7 Corrosion kinetics of $\mathrm{Al}_{2} \mathrm{Cu}$ in $0.5 \mathrm{M} \mathrm{H}_{3} \mathrm{PO}_{4}$ at $T=303 \mathrm{~K}$ for the exemplary chemical composition of the solutions: a double-layer capacitance and $\mathbf{b}$ charge-transfer resistance; capacitances were divided and resistances multiplied by the geometric surface area

time. Analogously, the charge-transfer resistance after $t=$ 576 min was high for the solution containing $\mathrm{Na}_{2} \mathrm{WO}_{4}(370$ vs $347 \Omega \mathrm{cm}^{2}$, Table 1). It indicates that there was no such a severe dealloying of the intermetallic phase as described above. The corrosion rate was calculated based on the concentration of aluminium $c_{\mathrm{Al}}$ and copper $c_{\mathrm{Cu}}$ in the solution and was equal to 21.58 and $8.27 \mathrm{~g} \mathrm{~m}^{-2}$ day ${ }^{-1}$ for $0.5 \mathrm{M} \mathrm{Na}_{3} \mathrm{PO}_{4}$ and $0.5 \mathrm{M} \mathrm{H}_{3} \mathrm{PO}_{4} / 0.2 \mathrm{M} \mathrm{Na}_{2} \mathrm{WO}_{4}$, respectively, at $\mathrm{pH}=2.2$. Thus, a rather weak inhibition effect was achieved with an inhibition efficiency equal to $62 \%$.

The inhibition effect was not observed for $\mathrm{pH}=3.9$ in $0.5 \mathrm{M} \mathrm{H}_{3} \mathrm{PO}_{4} / 0.2 \mathrm{M} \mathrm{Na}_{3} \mathrm{VO}_{4}$. The corrosion rate of the $\mathrm{Al}_{2} \mathrm{Cu}$ phase was higher when compared to the solution without this salt at the same $\mathrm{pH}\left(2.61 \mathrm{~g} \mathrm{~m}^{-2}\right.$ day $^{-1}$ with the $\mathrm{Na}_{3} \mathrm{VO}_{4}$ and $2.34 \mathrm{~g} \mathrm{~m}^{-2}$ day ${ }^{-1}$ without the $\left.\mathrm{Na}_{3} \mathrm{VO}_{4}\right)$. The charge-transfer resistance was also higher for the solution without sodium orthovanadate (Fig. 7b). The double-layer capacitance, calculated for the $\mathrm{Al}_{2} \mathrm{Cu}$ phase immersed in $0.5 \mathrm{M} \mathrm{H}_{3} \mathrm{PO}_{4} / 0.2 \mathrm{M} \mathrm{Na}_{3} \mathrm{VO}_{4}$, was between 12 and $14 \mu \mathrm{F} \mathrm{cm}{ }^{-2}$, which is close to the value typical for smooth metal surfaces $\left(20 \mu \mathrm{F} \mathrm{cm}^{-2}\right)$ [37]. Interestingly, much higher values, between 200 and $350 \mu \mathrm{F} \mathrm{cm}{ }^{-2}$, were obtained for the $\mathrm{Al}_{2} \mathrm{Cu}$ phase at $\mathrm{pH}=3.9$ in the solution without sodium orthovanadate when there was no selective corrosion. The same effect was reported in the literature for $\mathrm{Al}_{2} \mathrm{Cu}$ immersed in $0.1 \mathrm{M} \mathrm{NaCl}$ solution. The high electrical double-layer capacitance was attributed to the formation of hydroxide ions on the surface due to the oxygen reduction reaction [47].

$0.5 \mathrm{M} \mathrm{H}_{3} \mathrm{PO}_{4} / 0.2 \mathrm{M} \mathrm{Na}_{3} \mathrm{VO}_{4}$ and $0.5 \mathrm{M} \mathrm{H}_{3} \mathrm{PO}_{4} / 0.2 \mathrm{M}$ $\mathrm{Na}_{2} \mathrm{WO}_{4}$ solutions were then acidified to $\mathrm{pH}=1.0$. The impedance spectra of the $\mathrm{Al}_{2} \mathrm{Cu}$ were compared with those obtained for $0.5 \mathrm{M} \mathrm{H}_{3} \mathrm{PO}_{4}$ (Fig. 8). It can be seen that sodium tungstate, when dissolved in orthophosphoric acid at $\mathrm{pH}=1$, increased the corrosion rate of the intermetallic phase. High values of the double-layer capacitance indicate selective corrosion (Fig. 7a). The charge-transfer resistance decreased with time from 51 to $19 \Omega \mathrm{cm}^{2}$ (Table 1 ). The corrosion rate is 3fold higher when compared to that of a $0.5 \mathrm{M} \mathrm{H}_{3} \mathrm{PO}_{4}$ solution.

In the case of sodium orthovanadate $(200 \mathrm{mM}, \mathrm{pH}=1.0)$, the values of $R_{\mathrm{ct}}, L_{1}$ and $R_{1}$ increased with time (Table 1; Fig. 7b), whereas $C_{\mathrm{dl}}$ only slightly increased between 9 and $12 \mu \mathrm{F} \mathrm{cm}{ }^{-2}$. This was caused by the formation of the protective layer on the $\mathrm{Al}_{2} \mathrm{Cu}$ surface. The layer was composed mainly of vanadium, phosphorus, oxygen and sodium, where the $\mathrm{P} / \mathrm{V}$ atomic ratio was close to unity. The high-frequency capacitive loop $(f>$ $1 \mathrm{kHz}$ ), emerging at the impedance spectra (Fig. 8d), was related to the microporosity of this layer. However, the corrosion protection was only moderate, since the areas uncovered can be easily found on the surface (Fig. 3b). The corrosion rate of $\mathrm{Al}_{2} \mathrm{Cu}$ in $0.5 \mathrm{M} \mathrm{H}_{3} \mathrm{PO}_{4}$ was $47.12 \mathrm{~g} \mathrm{~m}^{-2}$ day $^{-1}$ and decreased to $39.93 \mathrm{~g} \mathrm{~m}^{-2}$ day $^{-1}$ in the solution containing initially $200 \mathrm{mM}$ of $\mathrm{Na}_{3} \mathrm{VO}_{4}$.

The most severe $\mathrm{Al}_{2} \mathrm{Cu}$ corrosion occurred in $0.5 \mathrm{M}$ $\mathrm{H}_{3} \mathrm{PO}_{4} / 0.01 \mathrm{M} \mathrm{Na}_{3} \mathrm{VO}_{4}(\mathrm{pH}=1.3), 0.5 \mathrm{M} \mathrm{H}_{3} \mathrm{PO}_{4} / 0.05 \mathrm{M}$ $\mathrm{Na}_{2} \mathrm{WO}_{4}(\mathrm{pH}=1.2)$ and $0.5 \mathrm{M} \mathrm{H}_{3} \mathrm{PO}_{4} / 0.2 \mathrm{M} \mathrm{Na}_{2} \mathrm{WO}_{4}(\mathrm{pH}$ $=1.0$ ) since the $\mathrm{pH}$ was strongly acidic, and the species formed in the solution acted as additional depolarisers in the corrosion cell. The surface area of these electrodes increased with time and was 1-3.5 thousand times higher when compared to the smooth surface (assumed capacitance $20 \mu \mathrm{F} \mathrm{cm}^{-2}$ [37]). Thus, the highest values of the doublelayer capacitance among the samples in this study were obtained (Fig. 7a). It should be noted here that fitted values of $\alpha$ were $<0.85$ for $200 \mathrm{mM} \mathrm{Na}_{2} \mathrm{WO}_{4}, \mathrm{pH}=1, t=159,298,437$ and $576 \mathrm{~min}$ as well as $10 \mathrm{mMNa}_{3} \mathrm{VO}_{4}, \mathrm{pH}=1.3, t=437$ and $576 \mathrm{~min}$. Thus, the errors of $C_{\mathrm{dl}}$ values in these cases can be significant [43]. The charge-transfer resistance, for selectively corroded specimens, decreased with time due to increase of the real surface area, and after $10 \mathrm{~h}$, reached low values between 10 and $30 \Omega \mathrm{cm}^{2}$. This is not related with the change of corrosion mechanism. $R_{\mathrm{ct}}$ values presented in Table 1 were multiplied by the geometric surface area. 


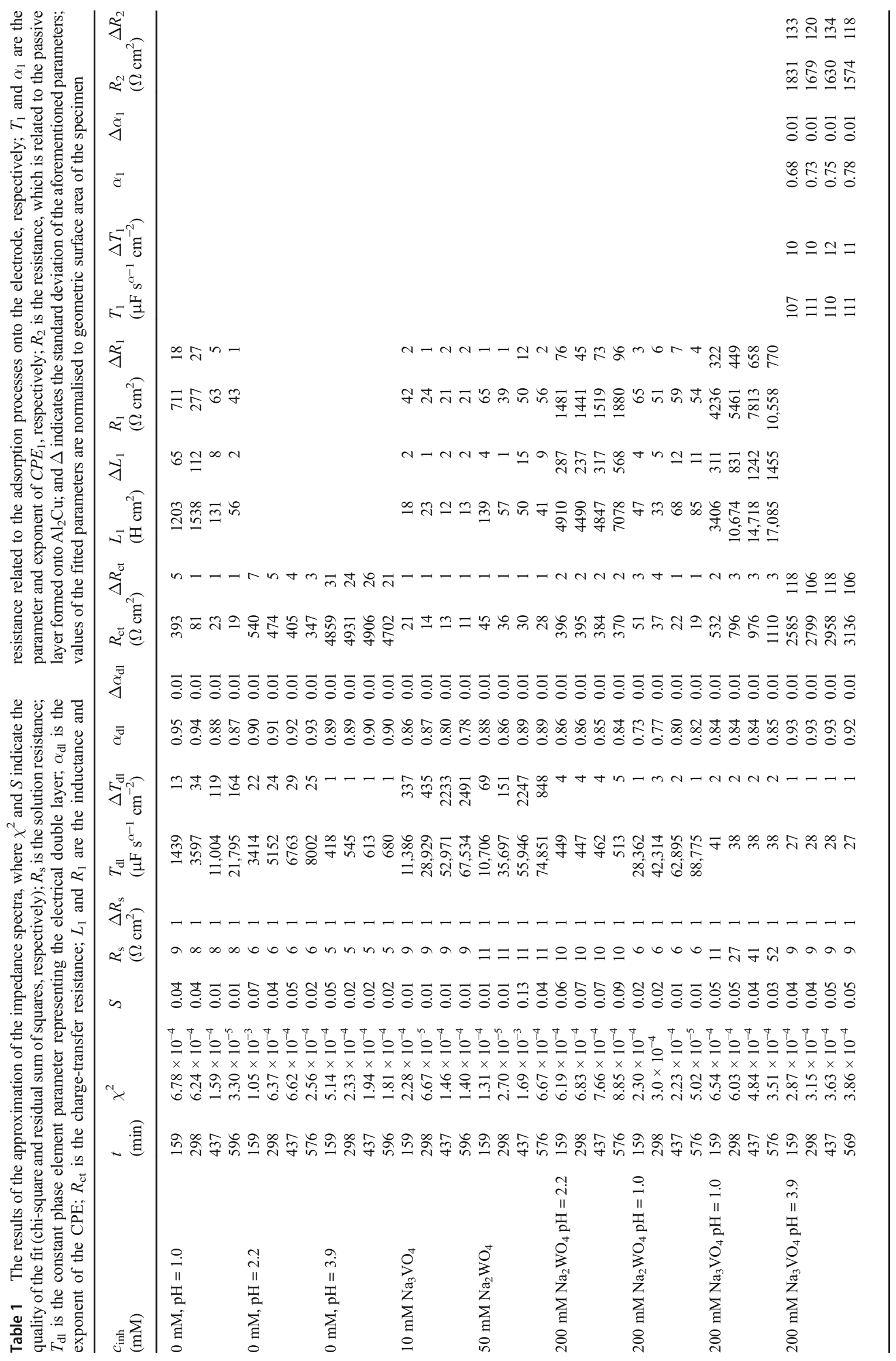


a)

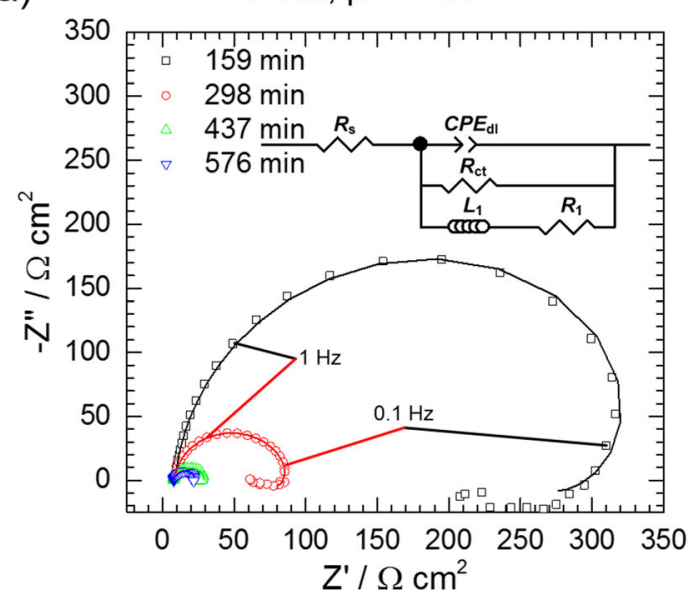

c) $200 \mathrm{mM} \mathrm{Na}_{3} \mathrm{VO}_{4}, \mathrm{pH}=1.0$

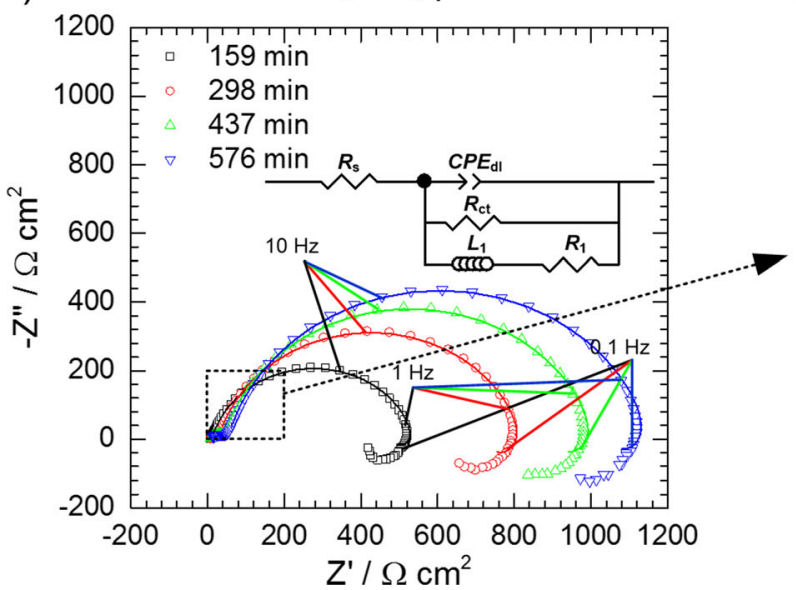

b)

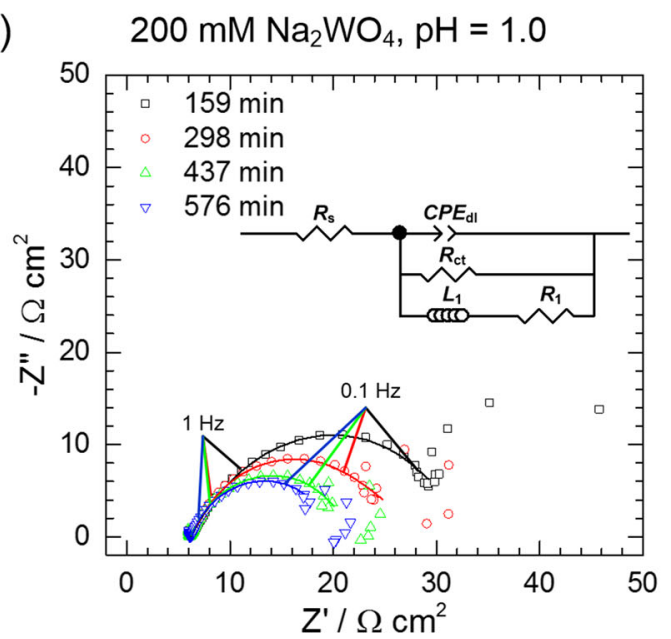

d)

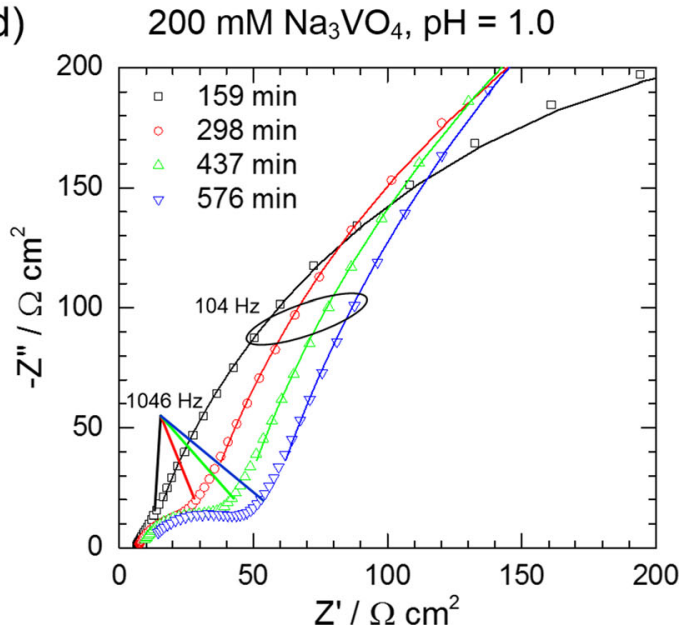

Fig. 8 Nyquist plots for the corrosion of $\mathrm{Al}_{2} \mathrm{Cu}$ in $0.5 \mathrm{M} \mathrm{H}_{3} \mathrm{PO}_{4}$ at $\mathrm{pH}=1$ and $T=303 \mathrm{~K}$ as a function of time and initial concentration of $\mathrm{Na}_{3} \mathrm{VO} \mathrm{O}_{4}$ and $\mathrm{Na}_{2} \mathrm{WO}_{4}$; continuous lines represent an approximation of the obtained data; impedances were multiplied by the geometric surface area

It can be concluded that corrosion inhibition of intermetallic $\mathrm{Al}_{2} \mathrm{Cu}$ in the $\mathrm{H}_{3} \mathrm{PO}_{4}-\mathrm{Na}_{3} \mathrm{VO}_{4}$ system did not occur. The vanadium in the studied solutions, where the $\mathrm{pH}$ was between 1 and 4 and its total concentration was between 10 and $200 \mathrm{mM}$, existed in two forms. The decavanadate $\left[\mathrm{H}_{2} \mathrm{~V}_{10} \mathrm{O}_{28}\right]^{4-}$ ion is stable for $\mathrm{pH}>2$ and a total concentration of vanadium > ca. $10 \mathrm{mM}$, whereas $\mathrm{VO}_{2}{ }^{+}$occurs in a more acidic solution and lower total $\mathrm{V}$ concentration. Upon addition of $\mathrm{Na}_{3} \mathrm{VO}_{4}$ to $0.5 \mathrm{M} \mathrm{H}_{3} \mathrm{PO}_{4}$, the solution turned dark redbrown. This indicates the formation of $\left[\mathrm{HPV}_{14} \mathrm{O}_{42}\right]^{9-}$ heteropolyoxovanadate [20]. However, neither the isopolyoxovanadates nor the heteropolyoxovanadates inhibited the corrosion of the $\mathrm{Al}_{2} \mathrm{Cu}$. At a sufficiently acidic solution $(\mathrm{pH}=1)$, the vanadium species were reduced on the surface of the electrode, and probably vanadium(IV) phosphate $\mathrm{VOHPO}_{4}: \mathrm{H}_{2} \mathrm{O}(x=0.5,4)$ was formed [48]. This result may be useful from the point of view of the preparation of conversion coatings on aluminium alloys.

In the case of sodium tungstate, the formation of heteropolyoxotungstate was confirmed using UV-Vis spectroscopy. The absorption band at ca. $260 \mathrm{~nm}$ appeared after dissolution of $\mathrm{Na}_{2} \mathrm{WO}_{4}$ in $0.5 \mathrm{M} \mathrm{H}_{3} \mathrm{PO}_{4}$. Thus, $[\alpha-$ $\left.\mathrm{PW}_{12} \mathrm{O}_{40}\right]^{3-}$ was present in the solutions, where the initial concentration of the monometalate was $\leq 100 \mathrm{mM}$. When the $\mathrm{pH}$ of the solution was raised above 1.5-2.0, it was reversibly converted to a lacunary $\left[\alpha-\mathrm{PW}_{11} \mathrm{O}_{39}\right]^{7-}$ anion, which also has an absorption band at approximately $260 \mathrm{~nm}$ [20]. This anion may be responsible for the weak inhibition effect observed for $200 \mathrm{mM}$ of $\mathrm{Na}_{2} \mathrm{WO}_{4}$ at $\mathrm{pH}=2.2$. However, the contribution of isopolyoxotungstate species present in the solution cannot be excluded.

\section{Summary}

Sodium orthovanadate, sodium tungstate and sodium molybdate were tested as corrosion inhibitors of intermetallic $\mathrm{Al}_{2} \mathrm{Cu}$ in $0.5 \mathrm{M} \mathrm{H}_{3} \mathrm{PO}_{4}$. When their concentration in orthophosphoric acid is too low, severe dealloying of the $\mathrm{Al}_{2} \mathrm{Cu}$ phase occurs. The inhibition effect, observed for $0.5 \mathrm{M} \mathrm{H}_{3} \mathrm{PO}_{4} / 0.2 \mathrm{M}$ 
$\mathrm{Na}_{3} \mathrm{VO}_{4}$ and $0.5 \mathrm{M} \mathrm{H}_{3} \mathrm{PO}_{4} / 0.2 \mathrm{M} \mathrm{Na}_{2} \mathrm{WO}_{4}$, is mainly related to the $\mathrm{pH}$ increase in the solution to the range, where the corrosion rate of the $\mathrm{Al}_{2} \mathrm{Cu}$ phase is low. However, these results do not necessarily exclude the above-mentioned isopolyoxoanions and heteropolyoxoanions as corrosion inhibitors of aluminium alloys in acidic solutions. Their influence on the corrosion behaviour of an $\mathrm{Al}-\mathrm{Cu}$ solid solution and other intermetallics in $\mathrm{H}_{3} \mathrm{PO}_{4}$ should also be studied. Sodium orthovanadate seems to be the least likely to replace $\mathrm{CrO}_{3}$ in stripping solutions for anodic coatings, since precipitation of insoluble salts during etching negatively affects the gravimetric determination of the coating weight.

Acknowledgments The authors gratefully acknowledge Dr. Dariusz Szeliga and Mr. Andrzej Gradzik for preparing the $\mathrm{Al}_{2} \mathrm{Cu}$ intermetallic phase, Dr. Barbara Kościelniak for her help in microscopic analysis, Mr. Andrzej Obłój for his help in conducting the electrochemical research and Prof. Andrzej Lasia for his help in interpretation of EIS data and valuable comments.

Funding information The National Science Centre, Poland, Grant No. 2016/23/D/ST5/01343 provided financial support.

Open Access This article is distributed under the terms of the Creative Commons Attribution 4.0 International License (http:// creativecommons.org/licenses/by/4.0/), which permits unrestricted use, distribution, and reproduction in any medium, provided you give appropriate credit to the original author(s) and the source, provide a link to the Creative Commons license, and indicate if changes were made.

\section{References}

1. Belov NA, Eskin DG, Aksenov AA (2005) Multicomponent phase diagrams: applications for commercial aluminum alloys. Elsevier, Oxford

2. Scully JR, Knight TO, Buchheit RG, Peebles DE (1993) Electrochemical characteristics of the $\mathrm{Al}_{2} \mathrm{Cu}, \mathrm{Al}_{3} \mathrm{Ta}$ and $\mathrm{Al}_{3} \mathrm{Zr}$ intermetallic phases and their relevancy to the localized corrosion of Al alloys. Corros Sci 35(1-4):185-195

3. Buchheit RG (1995) A compilation of corrosion potentials reported for intermetallic phases in aluminum alloys. J Electrochem Soc 142(11):3994-3996

4. Osório WR, Spinelli JE, Ferreira IL, Garcia A (2007) The roles of macrosegregation and of dendritic array spacings on the electrochemical behavior of an $\mathrm{Al}-4.5 \mathrm{wt} \% \mathrm{Cu}$ alloy. Electrochim Acta 52(9):3265-3273

5. Osório WR, Spinelli JE, Freire CMA, Cardona MB, Garcia A (2007) The roles of $\mathrm{Al}_{2} \mathrm{Cu}$ and of dendritic refinement on surface corrosion resistance of hypoeutectic $\mathrm{Al}-\mathrm{Cu}$ alloys immersed in $\mathrm{H}_{2} \mathrm{SO}_{4}$. J Alloys Compd 443(1-2):87-93

6. Al-Rawajfeh AE, Al Qawabah SMA (2009) Investigation of copper addition on the mechanical properties and corrosion resistance of commercially pure aluminium. Emirates J Eng Res 14:47-52

7. Osório WR, Siqueira CA, Santos CA, Garcia A (2011) The correlation between electrochemical corrosion resistance and mechanical strength of As-cast Al-Cu and Al-Si alloys. Int J Electrochem Sci 6: 6275-6289

8. Özay Ç, Gencer EB, Gökçe A (2018) Microstructural properties of sintered $\mathrm{Al}-\mathrm{Cu}-\mathrm{Mg}-\mathrm{Sn}$ alloys. J Therm Anal Calorim 5:23-33
9. Bonatti RS, Meyer YA, Bortolozo AD, Costa D, Wislei R (2019) Morphology and size effects on densification and mechanical behavior of sintered powders from $\mathrm{Al}-\mathrm{Si}$ and $\mathrm{Al}-\mathrm{Cu}$ casting alloys. J Alloys Compd 786:717-732

10. Lebouil S, Tardelli J, Rocca E, Volovitch P, Ogle K (2014) Dealloying of $\mathrm{Al}_{2} \mathrm{Cu}, \mathrm{Al}_{7} \mathrm{Cu}_{2} \mathrm{Fe}$, and $\mathrm{Al}_{2} \mathrm{CuMg}$ intermetallic phases to form nanoparticulate copper films. Mater Corros 65(4): 416-424

11. Sheasby PG, Pinner R, Wernick S (2001) The surface treatment and finishing of aluminium and its alloys. ASM International, Trowbridge

12. ASTM B137-95 (2009) Standard test method for measurement of coating mass per unit area on anodically coated aluminum. ASTM International, West Conshohocken PA

13. Iannuzzi M, Frankel GS (2007) Mechanisms of corrosion inhibition of AA2024-T3 by vanadates. Corros Sci 49(5):2371-2391

14. Ralston KD, Chrisanti S, Young TL, Buchheit RG (2008) Corrosion inhibition of aluminum alloy 2024-T3 by aqueous vanadium species. J Electrochem Soc 155(7):C350-C359

15. Ralston KD, Young TL, Buchheit RG (2009) Electrochemical evaluation of constituent intermetallics in aluminum alloy 2024-T3 exposed to aqueous vanadate inhibitors. J Electrochem Soc 156(4): C135-C146

16. Ralston KD, Buchheit RG (2013) An initial exploration of corrosion inhibition of AA6061 and AA7075 by aqueous vanadates. ECS Electrochem Lett 2(9):C35-C38

17. Kharitonov DS, Sommertune J, Örnek C, Ryl J, Kurilo II, Claesson PM, Pan J (2018) Corrosion inhibition of aluminium alloy AA6063-T5 by vanadates: local surface chemical events elucidated by confocal Raman micro-spectroscopy. Corros Sci 148:237-250

18. El Abedin SZ (2001) Role of chromate, molybdate and tungstate anions on the inhibition of aluminium in chloride solutions. J Appl Electrochem 31(6):711-718

19. Abd El Aal EE, Abd El Wanees S, Farouk A, Abd El Haleem SM (2013) Factors affecting the corrosion behaviour of aluminium in acid solutions: II. Inorganic additives as corrosion inhibitors for $\mathrm{Al}$ in $\mathrm{HCl}$ solutions. Corros Sci 68:14-24

20. Pope MT (1983) Heteropoly and isopoly oxometalates. SpringerVerlag, Berlin

21. Krebs B, Tytko KH, Mehmke J, Stiller S (1991) Structure and bonding in the high molecular weight isopolymolybdate ion, $\left[\mathrm{Mo}_{36} \mathrm{O}_{112}(\mathrm{H} 2 \mathrm{O})_{16}\right]^{8-}$. The crystal structure of $\mathrm{Na}_{8}\left[\mathrm{Mo}_{36} \mathrm{O}_{112}\left(\mathrm{H}_{2} \mathrm{O}\right)_{16}\right] .58 \mathrm{H}_{2} \mathrm{O}$. Eur J Solid State Inorg Chem 28: 883-903

22. Müller A, Krickemeyer E, Meyer J, Bögge H, Peters F, Plass W, Diemann E, Dillinger S, Nonnenbruch F, Randerath M (1995) $\left[\mathrm{Mo}_{154}(\mathrm{NO})_{14} \mathrm{O}_{420}(\mathrm{OH})_{28}\left(\mathrm{H}_{2} \mathrm{O}\right)_{70}\right]^{(25 \pm 5)-}$ : ein wasserlösliches Riesenrad mit mehr als 700 Atomen und einer relativen Molekülmasse von ca. 24000. Angew Chemie 107(19):2293-2295

23. Müller A, Botar B, Das SK, Bögge H, Schmidtmann M, Merca A (2004) On the complex hedgehog-shaped cluster species containing 368 Mo atoms: simple preparation method, new spectral details and information about the unique formation. Polyhedron 23(15):23812385

24. Li X, Deng S, Fu H (2011) Sodium molybdate as a corrosion inhibitor for aluminium in $\mathrm{H}_{3} \mathrm{PO}_{4}$ solution. Corros Sci 53(9):27482753

25. Badawy WA, Al-Kharafi FM (1997) The inhibition of the corrosion of $\mathrm{Al}, \mathrm{Al}-6061$ and $\mathrm{Al}-\mathrm{Cu}$ in chloride free aqueous media: I. passivation in acid solutions. Corros Sci 39(4):681-700

26. Nagul EA, McKelvie ID, Worsfold P, Kolev SD (2015) The molybdenum blue reaction for the determination of orthophosphate revisited : opening the black box. Anal Chim Acta 890:60-82

27. Kwolek P, Kamiński A, Dychtoń K, Drajewicz M, Sieniawski J (2016) The corrosion rate of aluminium in the orthophosphoric acid 
solutions in the presence of sodium molybdate. Corros Sci 106: 208-216

28. Dychtoń K, Kwolek P (2018) The replacement of chromate by molybdate in phosphoric acid-based etch solutions for aluminium alloys. Corros Eng Sci Technol 53(3):234-240

29. Kwolek P, Wojnicki M (2018) Spectrophotometric study of corrosion inhibition of aluminium in orthophosphoric acid aqueous solutions by using sodium molybdate. Corros Eng Sci Technol 54: 199-204

30. Kwolek P, Pustuła A, Nowak WJ (2019) Influence of molybdophosphoric acid on the kinetics of the anodic coating dissolution. Surf Coatings Technol 357:535-542

31. Boukamp B (1995) A linear Kronig-Kramers transform test for emittance data validation. J Electrochem Soc 142(6):1885-1894

32. Boukamp B (2004) Electrochemical impedance spectroscopy in solid state ionics: recent advances. Solid State Ionics 169(1-4):6573

33. Birbilis N, Buchheit RG (2008) Investigation and discussion of characteristics for intermetallic phases common to aluminum alloys as a function of solution $\mathrm{pH}$. J Electrochem Soc 155(3):C117-C126

34. Tran A-T, Huet F, Ngo K, Rousseau P (2011) Artefacts in electrochemical impedance measurement in electrolytic solutions due to the reference electrode. Electrochim Acta 56:8034-8039

35. Frateur I, Deslouis C, Orazem ME, Tribollet B (1999) Modeling of the cast iron/drinking water system by electrochemical impedance spectroscopy. Electrochim Acta 44(24):4345-4356

36. Park JJ, Pyun S II (2003) Analysis of impedance spectra of a pitted Inconel alloy 600 electrode in chloride ion-containing thiosulfate solution at temperatures of 298-573 K. J Solid State Electrochem 7(6):380-388

37. Chen L, Lasia A (1992) Study of the kinetics of hydrogen evolution reaction on nickel-zinc powder electrodes. J Electrochem Soc 139(11):3214-3219

38. Chen L, Lasia A (1993) Ni-Al powder electrocatalyst for hydrogen evolution. J Electrochem Soc 140(9):2464-2473
39. Pyun S-I, Shin H-C, Lee J-W, Go J-Y (2012) Electrochemistry of insertion materials for hydrogen and lithium. Springer-Verlag, Berlin

40. Lasia A (2014) Electrochemical impedance spectroscopy and its applications. Springer, New York

41. Ma H, Cheng X, Li G, Chen S, Quan Z, Zhao S, Niu L (2000) The influence of hydrogen sulfide on corrosion of iron under different conditions. Corros Sci 42(10):1669-1683

42. Hirschorn B, Orazem ME, Tribollet B, Vivier V, Frateur I, Musiani M (2010) Determination of effective capacitance and film thickness from constant-phase-element parameters. Electrochim Acta 55(21): $6218-6227$

43. Łosiewicz B, Jurczakowski R, Lasia A (2017) Kinetics of hydrogen underpotential deposition at iridium in sulfuric and perchloric acids. Electrochim Acta 225:160-167

44. Cao C (1990) On the impedance plane displays for irreversible electrode reactions based on the stability conditions of the steady state II. Two state variables besides electrode potential. Electrochim Acta 35(5):837-844

45. Umoren SA, Li Y, Wang FH (2010) Effect of polyacrylic acid on the corrosion behaviour of aluminium in sulphuric acid solution. $\mathrm{J}$ Solid State Electrochem 14(12):2293-2305

46. Arutunow A, Darowicki K (2009) Impact of sensitization on dissolution process of AISI 304 stainless steel during intergranular corrosion evaluated using DEIS technique. J Solid State Electrochem 13(11):1687-1694

47. Rajan V, Neelakantan $\mathrm{L}$ (2017) On the corrosion behavior of $\mathrm{Al}_{2} \mathrm{Cu}$ by local electrochemical impedance spectroscopy using droplet cell microscopy. J Solid State Electrochem 21(2):603-609

48. Dummer NF, Bartley JK, Hutchings GJ (2011) Vanadium phosphate materials as selective oxidation catalysts. Adv Catal 54: 189-247

Publisher's note Springer Nature remains neutral with regard to jurisdictional claims in published maps and institutional affiliations. 